\title{
Balanced Scorecard Critical Success Factors of Jordanian Commercial Banks and Its Effect on Financial Performance
}

\author{
Dr. Mohanad Fayiz Saleem AL-Dweikat ${ }^{1} \&$ Prof. Mohmoud Ibrahim Nour $^{1}$ \\ ${ }^{1}$ Financial Management, Al-Isra University, Amman, The Hashemite Kingdom of Jordan. \\ Correspondence: Mohanad Fayiz Saleem AL-Dweikat, Al-Isra University, The Hashemite Kingdom of Jordan.
}

Received: May 28, 2018

Accepted: June 21, 2018

Online Published: June 25, 2018

doi:10.5430/afr.v7n3p146

URL: https://doi.org/10.5430/afr.v7n3p146

\begin{abstract}
The present study aimed to identify the Critical Success Factors of balanced scorecard at Jordanian Commercial Banks, as well as, reveal its effect on Financial Performance The study adapts the quantitative method to achieve their objectives. A randomaly sample of the employees of the higher and middle administrations (managers, deputies, their assistants and sector managers) at Jordanian Commercial Banks selected totaling (120) individuals. Exploratory Factor Analysis, Reliability, Confirmatory Factor Analysis and Structural equation Modelling was performed. The results indicate that the Top Management, Strategic intent, HR aspects and Systems and techniques are Critical Success Factors of balanced scorecard with reliable and valid. Inaddition, the Top Management, Strategic intent, HR aspects and Systems and techniques Success Factors positively effect on financial performance at Jordanian Commercial Banks.
\end{abstract}

Keywords: critical success factors, balanced scorecard, financial performance, jordanian commercial banks and structural equation modeling.

\section{Introduction}

The rapid development of information technology and globalization in the last century has led to global dynamism in all spheres of life. Hence, the countries of the world have recognized the importance of positive interaction with this openness and the importance of dealing with it. This great interest in globalization and information technology in these countries lead to transformation of their societies into information societies, characterized by their reliance on the power of information and knowledge, rather than on other elements of wealth, focused on the knowledge-based economy and information technology. As well as, the quick changes in the contemporary banking environment have affected the quantity and quality of information that banks need to measure and evaluate performance to achieve their desired objectives and to keep abreast of these recent developments and improve their strategy.

Based on above, Balanced Scorecard emerged with its four perspectives (financial, internal business processes, customers, learning and growth) for performance measurement. The Balanced Scorecard is a modern administrative system that seeks to achieve administrative efficiency by evaluating performance via indicators that reflect the balance in the objectives of the organization.

Based on above, this study came to identify the Critical Success Factors of balanced scorecard at Jordanian Commercial Banks, as well as, reveal its effect on Financial Performance.

\subsection{Study Problem and Its Questions}

The fact that the commercial banking sector is the most widespread sector in most countries in addition to its role in the development of countries especially in recent years, which witnessed an unprecedented transformation of this sector. With the rapid development of the environment has become more complex and dynamic, the commercial banking sector foucs on customers and to know their needs and aspirations more in a manner that achieves high levels of financial performance.

The commercial banking sector seeks to win the satisfaction of existing customers and attract the largest number of potential customers by making it more capable to cope with environmental changes in a way that enables it to achieve high levels of financial performance. Because commercial banks, including Jordanian commercial banks are still facing turbulent conditions resulting from changes in the external environment, they have been required to benefit from contemporary methods and approaches, including the critical success factors of the Balanced Scorecard 
in order to achieve superior financial performance. As well as, the previous studies at the Arab level, which dealt with the success factors of the implemented the Balanced Scorecard in commercial banks and the impact of these factors on financial performance is limited.

Accordingly, it can represent the current research problem by raising the following question:

1. Does the Critical Success Factors of balanced scorecard (Top Management, Strategic intent, HR aspects and Systems and techniques) are reliable and valid?

2. To what extant the Critical Success Factors of balanced scorecard (Top Management, Strategic intent, HR aspects and Systems and techniques) effect on Financial Performance at Jordanian Commercial Banks?

\subsection{Objective of the Study}

The objectives of this research related to identify the validity of the Critical Success Factors of balanced scorecard at Jordanian Commercial Banks, as well as, investigate the effect of Critical Success Factors of balanced scorecard on Financial Performance in Jordanian Commercial Banks.

\subsection{Significance of the Study}

The significance of the current study stems from a great number of instruments has been adopted in many studies. The significance of the current study stems from the lack of scale to identify the Critical Success Factors of balanced scorecard on the Arab content, especially, at Jordanian Commercial Banks.

\section{Literature Review}

\subsection{Balanced Scorecard}

The emergence of the Balanced Scorecard techniuue is a revolution against traditional reliance on accounting statements. It is a set of financial and non- financial measures that reflect the key and important factors that make the organization succeed. It has rapidly become a strategic tool for organization to improve their performance in general. These techniuue became known after Kaplan \& Norton published an article in the Harvard Business Review in 1992 to study the performance appraisal system of twelve companies (Saad, et al., 2016). Since 1992, numerous articles have been published in various fields that have shown the importance of the Balanced Scorecard and its benefits as a techniuue of deploying strategy everywhere in the organization to achieve and enhance its success (Kaplan \& Norton, 1996). Niven (2002) define Balanced Scorecard as a method that assists organizations to transmit their strategies in the form of a set of operational goals to various parts of organizations. Thus it transforms performance behavior of the whole organization. Horngren, e al., (2012) define Balanced Scorecard as a system for interpreting an organization's mission and strategy in in an integrated set of measures to performance measurement through providing a structure for implementation Organization's strategy via focusing on achieving financial objectives and non-financial objectives. This is why Balanced Scorecard is considered as a one of the techniques that enables organizations to evaluate their work in a comprehensive through four perspectives, rather than just on a financial perspective. The financial perspective includes financial objectives such as return on investment, profitability and cash flow, customer perspective which adds value to customers by offering innovative services with high quality and low prices in order to know customer satisfaction, internal business process perspective that concerned with all the internal activities and events that characterize the organization in order to achieve customer satisfaction and achieve the strategic goals of the organization, learning and growth perspective which is the basis for the Organization to generate the growth and improvements that required to achieve its long-term goals (Kaplan \& Norton, 1992).

\subsection{Critical Success Factors}

The concept of critical success factors is one of the concepts that have been increasingly used in the business environment. This concept was developed by Ronald Daniel at the Harvard Business School to in the early 1960s. As well as, the idea of critical success factors then developed by Rochart in 1986 (Michaels, 2008). Hilton, et al., (2003) define critical success factors as a strengths that are primarily responsible for the success of economic unity. These factors enable the unit to compete with its competitors by identifying these factors and incorporating them into the strategic plan to be able to maintain a competitive position, addition, exploit these critical success factors to improve the competitive advantage of economic unity. Thompson \& Strickland (2003) mark it as a influential things in the ability of economic unity to succeed in markets. In another context, Blocher, et al., (2002) referred to critical success factors as financial and non-financial indicators that measure the performance and ability of the economic unit to remain in the business environment. 


\subsection{Critical Success Factors of Balanced Scorecard}

Balanced Scorecard success factors vary according to the researchers' perspectives. Kaplan \& Norton (2001) identified five Critical Success Factors for balanced scorecard, the first, Translate the Strategy to Operational Terms, second, Align the organization to the strategy, third, Make strategy everyone's job, fourth, Make strategy a continual process, finally, Mobilize Change through Executive leadership. Nair (2004) suppose the: Understand organizations Self, Understand the BSC Learning Cycle, Know the Road Map for Implementation, Treat BSC as a Project, Use Technology as an Enabler and Cascade the Scorecard. As well as, Aravamudgan \& Kamalanabhan (2007) in their work define Critical Success Factors for balanced scorecard implementation as follows: (1) Top management, the most definite factor in the implementation of the BSC is "top management support" towards building a strategyfocused organization. CEOs are the most individual in any organization responsible to the BSC. The top management must have clear understanding of the purpose, outcomes and benefits of implementing the BSC in the organization. In order to prompt the BSC process and achieve the expected goals the top management should have clear and one strategy. (2) Strategic intent, any organization wants to adopt the BSC must have clear mission and vision statements because they consider as an essential resources to develop strategy map and the BSC process. Even if there are mission and vision statements, the successful implementation also needs strategic awareness among the employees of the organization. (3) HR aspects, the top management may use the scorecard information to make strategic decisions. "The BSC strategic management system works best when used to communicate vision and strategy, not to control the actions of the subordinates." Employee attitudes towards the BSC adoption are important because the implementation of the BSC depends on employees' participation towards the BSC. Educating and training the employees of the organization, in all positions, especially supervisors and middle managers about the BSC measurement and management system for implementing strategies is very important. If the top management feels the need to hire consultant, it is better to select consultants who have broad experience on BSC implementation. (4) Systems and techniques include all the technical and functional facets regarding implementing BSC. Any organization adopts the BSC must have four elements that would enable easy implementation of the BSC. These four elements are: communication mechanisms; communication mechanisms like e-mail and meetings helps the organization to know the role of BSC. IT infrastructure; technological development is very important for effective and successful implementation of BSC. BSC software utilization and Effective measurement culture; it is deals with data availability in all forms related to BSC. If the organization wants to benefit from the BSC methodology, it needs new ways of data collection because all decisions of the organization are derived from data collection.

In this research the researchers adopt the Aravamudgan \& Kamalanabhan (2007) because these factors are the most comprehensive and clear in the implementation of the balanced scorecard, in addition to being the appropriate factors for application in the Arab environment, especially the environment of Jordanian commercial banks.

\subsection{Financial Performance}

Lynch (2006) argues that the financial performance will remain the indicator for organizations' success; the failure of organizations to achieve financial performance at the required basic level jeopardizes their presence and continuity. Venkatraman \& Ramanujam (1986) argues that financial performance is the most common field of performance in most strategic management research. Harrison \& John (1998) believes that financial performance indicators can be used as key indicators used in the organization's internal analysis, financial performance is an important strategy that managers can use it to determine the overall level of performance in the organization. Vecchio (1995) emphaziz that they are two main reasons for the wide use of financial indicators for performance. First, financial performance indicators, such as profit, are directly related to the organization's long-term goals, which are always financial objectives. Second, the very precise choice of financial indicators provides a comprehensive picture of the organization's performance.

\subsection{Critical Success Factors of BSC, Financial Performance and Hypotheses Development}

Davis \& Albright (2004) through reveal that the superior financial performance for branches implementing the BSC when compared to non-BSC implementing branches. AL-Mawali, et al., (2010) found there is a positive relationship between the usages of multiple performance measures via overall BSC measures and financial performance in the Jordanian Banking Industry Branches. Muli (2016) explained that the implementation of balance scorecard was found to lead to increased profitability of the firms. Majority indicated that implementation of the balance score card is positively related to financial performance of their firms. Sweiti \& Lele (2016) reveal that the adoption of Balanced Scorecard significantly improves the revenue growth. Finally, Malagueño, et al., (2018) found that firms using BSC for feedforward control obtained better financial performance. 
Based on the previous researchers founding, the researcher's development the following Hypotheses:

Ha1: Top management success factor positively effect on financial performance.

Ha2: Strategic intent success factor positively effect on financial performance.

Ha3: HR aspects success factor positively effect on financial performance.

Ha4: Systems and techniques success factor positively effect on financial performance.

\section{Study Methodology}

\subsection{Research Methods}

In this research the researchers adapt the quantitative method through collecting and analysing data obtaining from the responds form Jordanian commercial banks. As well as, the Reason for adoption the quantitative method because the quantitative method usually using statistical analysis to gain an understandable and meaningful conclusion of the research (Creswell and Clark, 2010).

\subsection{Population and Sample}

The study population consists of employees of the higher and middle administrations (directors, deputies, assistants and sector managers) in Jordanian commercial banks. a (120) individuals randomaly sample of the employees of the higher and middle administrations (managers, deputies, their assistants and sector managers) was selected from the Jordanian commercial banks. A copy of the questionnaire has been given to each responder in order to answer the questions on the questionnaire as best. Participation in the investigation was completely voluntary. All responses remain confidential and anonymous.

\subsection{Measurement \& Data Analysis}

This study adopts numerous statistical techniques through using Statistical Package for the Social Sciences software, such as mean, standard deviation, Exploratory, Reliability, as well as, the study performed Amos programing through using Confirmatory Factor Analysis and Structural equation Modelling. The researchers identified Critical Success Factors of Balanced Scorecard based on Aravamudgan \& Kamalanabhan (2007). As well as, the scale of financial performance was adapted based on Croteau \& Raymond (2004). All scales measured in a five-point Likert-scale format from strongly disagree" (1) to "strongly agree" (5).

\section{Analysis and Results}

\subsection{Descriptive Statistic, Exploratory Factor Analysis and Reliability}

Mean and standard deviation for the variables are depicted below in Table 1, as well as, Exploratory Factor analysis was performed to evaluate the implicit Critical Success Factors of Balanced Scorecard. According to Hair, et..al., (2010) three suppositions to Exploratory Factor analysis were followed, Kaiser-Meyer-Olkin measure greater than 0.50; Eigen value to each factor must to be one and factor loading of 0.50 for each item. Indeed, reliability indicates the dependability and consistency in research findings. The KMO measure was (0.833), Bartlett's test of Sphericity Chi-square $\chi^{2}$ was statistically significant $(\mathrm{p} \leq 0.00)$ in all cases. In addition to that, eigen values for the resulting factors in the cases of all constructs were greater than one (1), and all items had loadings greater than (0.50). A total variance explained $62.939 \%$. The top management factor explaining $36.569 \%$ of the total variance. The strategic intent factor explaining $11.049 \%$ of the total variance. The HR aspects factor explaining $9.079 \%$ of the total variance. Finally, The systems and techniques explaining $6.242 \%$ of the total variance. Reliability coefficients ranging from $(0.761)$ to $(0.810)$. Then, all reliability coefficients were above the threshold value $(0.70)$ suggested by Hair, et..al., (2010). 
Table 1. Descriptive Statistics, Exploratory Factor Analysis (Critical Success Factors of BSC)

\begin{tabular}{|c|c|c|c|c|c|c|c|}
\hline $\begin{array}{l}\text { Items } \\
\text { No. }\end{array}$ & Mean & $\begin{array}{l}\text { Standard } \\
\text { Deviation }\end{array}$ & $\begin{array}{l}\text { Factor (1) } \\
\text { Top Management }\end{array}$ & $\begin{array}{l}\text { Factor (2) } \\
\text { Strategic intent }\end{array}$ & $\begin{array}{l}\text { Factor (3) } \\
\text { HR aspects }\end{array}$ & $\begin{array}{l}\text { Factor (4) } \\
\text { Systems and techniques }\end{array}$ & Communality \\
\hline Q1 & 3.791 & 0.915 & 0.640 & & & & 0.618 \\
\hline Q2 & 4.066 & 0.752 & 0.766 & & & & 0.670 \\
\hline Q3 & 4.041 & 0.726 & 0.727 & & & & 0.621 \\
\hline Q4 & 4.183 & 0.777 & 0.613 & & & & 0.668 \\
\hline Q5 & 4.091 & 0.819 & 0.577 & & & & 0.638 \\
\hline Q6 & 3.891 & 0.828 & & 0.539 & & & 0.610 \\
\hline Q7 & 4.133 & 0.672 & & 0.740 & & & 0.621 \\
\hline Q8 & 4.241 & 0.744 & & 0.722 & & & 0.635 \\
\hline Q9 & 4.208 & 0.798 & & 0.828 & & & 0.747 \\
\hline Q10 & 4.166 & 0.748 & & 0.681 & & & 0.636 \\
\hline Q11 & 4.108 & 0.828 & & & 0.676 & & 0.665 \\
\hline Q12 & 3.950 & 0.848 & & & 0.851 & & 0.776 \\
\hline Q13 & 3.900 & 0.771 & & & 0.722 & & 0.728 \\
\hline Q14 & 3.791 & 0.906 & & & 0.548 & & 0.550 \\
\hline Q15 & 4.183 & 0.744 & & & 0.646 & & 0.594 \\
\hline Q16 & 3.933 & 0.785 & & & & 0.676 & 0.623 \\
\hline Q17 & 3.841 & 0.788 & & & & 0.680 & 0.642 \\
\hline Q18 & 3.975 & 0.814 & & & & 0.770 & 0.634 \\
\hline Q19 & 4.058 & 0.802 & & & & 0.719 & 0.588 \\
\hline Q20 & 4.158 & 0.809 & & & & 0.602 & 0.525 \\
\hline \multicolumn{3}{|c|}{ Eigenvalue } & 7.314 & 2.210 & 1.816 & 1.248 & - \\
\hline \multicolumn{3}{|c|}{ Cronbach's alpha } & 0.761 & 0.814 & 0.779 & 0.820 & - \\
\hline \multicolumn{3}{|c|}{ Total Variance Explained } & 62.939 & - & - & - & - \\
\hline
\end{tabular}

4.2 Confirmatory Factor Analysis of Critical Success Factors of Balanced Scorecard Constructs - Multiple Factor

A total of 20 items running, the range model fit was good. The RMSEA value was 0.043 , which indicated good fit. Also, CMIN/DF indicated a good fit model with a value of (1.217). In contrast, GFI and AGFI values were 0.979 and 0.923 , respectively. Both values were within acceptable limits. In addition, NFI, TLI and CFI values were 0.965, 0.963 and 0.972 , respectively, all values were within acceptable limits. All the factor loadings were over 0.50 and all critical ratios were higher than 1.96, as shown in table 2 . Table 2 shows the overall fit indices for measurement model with all construct.

Table 2. Overall fit indices of Balanced Scorecard Success Factors Measurement Model with all constructs

\begin{tabular}{llllllll}
\hline Model & RMSEA & CMIN/DF & GFI & AGFI & NFI & TLI & CFI \\
\hline Default model & 0.043 & 1.217 & 0.979 & 0.923 & 0.965 & 0.963 & 0.972 \\
Saturated model & & & 1.000 & & 1.000 & 1.000 \\
Independence model & 0.220 & 6.782 & 0.296 & 0.222 & 0.000 & 0.000 & 0.000 \\
\hline
\end{tabular}

From the table 2, the measurement model with all constructs showed a good fit for all indices. Table 3 shows path loading, critical ratios (C.R), and R square values in the Balanced Scorecard Success Factors Measurement Model with all Constructs. All standardized regression weight values were (>0.5), and all of the critical ratios (C.R.) were (>1.96). Janssens et al., (2008) argue that the factor loading for each latent variable must be equal to or greater than $(0.50)$, and must also be significant (C.R. $=\mathrm{t}$-value $>1.96)$. as well as, the convergent validity by calculate the average variance extracted (AVE) and construct reliability by calculate the composite reliabilities (CR). The values 
of the (AVE) greater than (0.50) as recommended from Malhotra and Stanton (2004). In addition, a composite reliability $(\mathrm{CR})$ index greater than $(0.70)$ that indicates satisfactory internal consistency as recommended from Hair, et..al., (2010).

Table 3. Estimated values of Balanced Scorecard Success Factors Measurement Model with all constructs

\begin{tabular}{|c|c|c|c|c|c|c|c|c|}
\hline $\begin{array}{l}\text { Structural } \\
\text { Relation }\end{array}$ & $\begin{array}{l}\text { Regression } \\
\text { weight }\end{array}$ & $\begin{array}{l}\text { Standard } \\
\text { Error }\end{array}$ & $\begin{array}{l}\text { Critical } \\
\text { Ratio }\end{array}$ & $\mathrm{P}$ & $\begin{array}{l}\text { Standardized } \\
\text { Regression } \\
\text { weights }\end{array}$ & $\begin{array}{l}\text { Squared multiple } \\
\text { Correlation }\end{array}$ & AVE & $\mathrm{CR}$ \\
\hline Top Management $\rightarrow$ TM1 & 1.000 & & & & 0.505 & 0.255 & & \\
\hline Top Management $\rightarrow$ TM2 & 1.647 & 0.665 & 2.478 & 0.013 & 0.508 & 0.258 & & \\
\hline Top Management $\rightarrow$ TM3 & 2.418 & 1.075 & 2.250 & 0.024 & 0.609 & 0.370 & 62.131 & 78.461 \\
\hline Top Management $\rightarrow$ TM4 & 3.610 & 1.691 & 2.135 & 0.033 & 0.849 & 0.720 & & \\
\hline Top Management $\rightarrow$ TM5 & 3.297 & 1.550 & 2.127 & 0.033 & 0.746 & 0.556 & & \\
\hline Strategic intent $\rightarrow$ SI6 & 1.000 & & & & 0.668 & 0.446 & & \\
\hline Strategic intent $\rightarrow$ SI7 & 0.767 & 0.145 & 5.296 & $* * *$ & 0.635 & 0.403 & & \\
\hline Strategic intent $\rightarrow$ SI8 & 1.128 & 0.186 & 6.066 & $* * *$ & 0.828 & 0.685 & 76.569 & 85.582 \\
\hline Strategic intent $\rightarrow$ SI 9 & 1.021 & 0.195 & 5.231 & $* * *$ & 0.735 & 0.540 & & \\
\hline Strategic intent $\rightarrow$ SI10 & 1.095 & 0.205 & 5.337 & $* * *$ & 0.808 & 0.652 & & \\
\hline HR aspects $\rightarrow$ HR11 & 1.000 & & & & 0.729 & 0.531 & & \\
\hline $\mathrm{HR}$ aspects $\rightarrow \mathrm{HR} 12$ & 0.681 & 0.136 & 4.994 & $* * *$ & 0.575 & 0.330 & & \\
\hline $\mathrm{HR}$ aspects $\rightarrow \mathrm{HR} 13$ & 0.879 & 0.137 & 6.402 & $* * *$ & 0.670 & 0.448 & 59.985 & 78.068 \\
\hline $\mathrm{HR}$ aspects $\rightarrow \mathrm{HR} 14$ & 1.026 & 0.151 & 6.803 & $* * *$ & 0.674 & 0.454 & & \\
\hline $\mathrm{HR}$ aspects $\rightarrow \mathrm{HR} 15$ & 0.710 & 0.122 & 5.822 & $* * *$ & 0.571 & 0.326 & & \\
\hline Systems and techniques $\rightarrow$ ST16 & 1.000 & & & & 0.630 & 0.396 & & \\
\hline Systems and techniques $\rightarrow$ ST17 & 1.300 & 0.189 & 6.871 & $* * *$ & 0.822 & 0.675 & & \\
\hline Systems and techniques $\rightarrow$ ST18 & 1.052 & 0.172 & 6.116 & $* * *$ & 0.644 & 0.414 & 68.795 & 82.023 \\
\hline Systems and techniques $\rightarrow$ ST19 & 1.067 & 0.172 & 6.189 & $* * *$ & 0.664 & 0.440 & & \\
\hline Systems and techniques $\rightarrow$ ST20 & 1.124 & 0.185 & 6.077 & $* * *$ & 0.687 & 0.471 & & \\
\hline
\end{tabular}

\subsection{Hypotheses Testing}

The Testing hypotheses, the researcher used Structural equation Modelling to determining the effect between study variables.

Ha1: Top management success factor positively effect on financial performance.

Table 4. Top management success factor $\rightarrow$ financial performance

\begin{tabular}{|c|c|c|c|c|c|c|c|}
\hline \multirow{2}{*}{ Hypothesis } & \multicolumn{2}{|c|}{ Regression Weights } & \multirow{2}{*}{ Estimate } & \multirow{2}{*}{ SE } & \multirow{2}{*}{ C.R. } & \multirow{2}{*}{$P$ value } & \multirow{2}{*}{ Result } \\
\hline & From & To & & & & & \\
\hline HaI & TMSF & FP & 0.266 & 0.087 & 3.075 & 0.002 & Accepted \\
\hline
\end{tabular}

Table (4) presents each parameter's C.R., Estimate and S.E. Hence, Top management success factor positively effect on financial performance $(\beta=0.266, C . R=3.075$; P-value $=0.002)$ or Ha1 is supported.

Ha2: Strategic intent success factor positively effect on financial performance.

Table 5. Strategic intent success factor $\rightarrow$ financial performance

\begin{tabular}{llllllll}
\hline \multirow{2}{*}{ Hypothesis } & Regression Weights & & Estimate & SE & C.R. & P value & Result \\
\cline { 2 - 7 } & From & To & & & & & \\
\hline $\boldsymbol{H a 2}$ & SISF & FP & 0.258 & 0.098 & 2.632 & 0.009 & Accepted \\
\hline
\end{tabular}


Table (5) presents each parameter's C.R., Estimate and S.E. Hence, Strategic intent success factor positively effect on financial performance ( $\beta=0.258$, C.R $=2.632$; P-value $=0.007$ ) or Ha2 is supported.

Ha3: HR aspects success factor positively effect on financial performance.

Table 6. HR aspects success factor $\rightarrow$ financial performance

\begin{tabular}{llllllll}
\hline \multirow{2}{*}{ Hypothesis } & Regression Weights & & Estimate & SE & C.R. & P value & Result \\
\cline { 2 - 7 } & From & To & & & & & Accepted \\
\hline Ha3 & HRSF & FP & 0.439 & 0.110 & 3.815 & $* * *$ & Acted \\
\hline
\end{tabular}

Table (6) presents each parameter's C.R., Estimate and S.E. Hence, HR aspects success factor positively effect on financial performance $(\beta=0.439$, C.R $=3.815$; P-value $=* * *)$ or Ha3 is supported.

Ha4: Systems and techniques success factor positively effect on financial performance.

Table 7. Systems and techniques success factor $\rightarrow$ financial performance

\begin{tabular}{llllllll}
\hline \multirow{2}{*}{ Hypothesis } & \multicolumn{2}{l}{ Regression Weights } & Estimate & SE & C.R. & P value & Result \\
\cline { 2 - 7 } & From & To & & & & & \\
\hline Ha4 & HRSF & FP & 0.274 & 0.097 & 2.650 & 0.008 & Accepted \\
\hline
\end{tabular}

Table (7) presents each parameter's C.R., Estimate and S.E. Hence, Systems and techniques success factor positively effect on financial performance $(\beta=0.274, \mathrm{C} . \mathrm{R}=2.650$; $\mathrm{P}$-value $=0.008)$ or $\mathrm{Ha} 4$ is supported.

\section{Conclusions and Implications}

This study provides an empirical study of the Critical Success Factors of balanced scorecard with reliable and valid at Jordanian Commercial Banks. The results of the structural equation modeling provide support for the all hypotheses.Consistent with Top management success factor positively effect on financial performance at Jordanian Commercial Banks consistent with research result of Davis \& Albright (2004) that reveal the superior financial performance for branches implementing the BSC when compared to non-BSC implementing branches. as well as, Strategic intent success factor positively effect on financial performance at Jordanian Commercial Banks consistent with research result of AL-Mawali, et al., (2010) that found there is a positive relationship between the usages of multiple performance measures via overall BSC measures and financial performance in the Jordanian Banking Industry Branches. HR aspects success factor positively effect on financial performance at Jordanian Commercial Banks consistent with research result of Sweiti \& Lele (2016) that reveal the adoption of Balanced Scorecard significantly improves the revenue growth. Finally, Systems and techniques success factor positively effect on financial performance at Jordanian Commercial Banks consistent with research result of Malagueño, et al., (2018) that found firms using BSC for feedforward control obtained better financial performance.

The current study makes contributions through discover the Critical Success Factors of balanced scorecard, present a testable scales that are both reliable and valid through exploratory and confirmatory factor analysis. as well as, the poor of scale of Critical Success Factors of balanced scorecard. the managerial implications, cover most of the Critical Success Factors of balanced scorecard used in the organizations which will affect the levels of excellence financial performance on the long range

\section{References}

Al-mawali, H; Zainuddin, Y \& Kader Ali, N. (2010). Balanced scorecard (BSC) usage and financial performance of branches in Jordanian banking industry. World Academy of Science: Engineering and Technology, 42, 1174-1181. https://doi.org/10.1999/1307-6892/10195

Aravamudgan, S \& Kamalanabhan, T. (2007). An AHP Study on the Critical Factors for balanced scorecard implementation in Indian organizations. International Journal of business innovation and Research, 1(4), 387 403. https://doi.org/10.1504/IJBIR.2007.013726

Blocher, E; Chen, H \& Lin, W. (2002). Cost Management: A strategic Emphasis. $2^{\text {nd }}$ edition, McGraw - Hill, N.Y.

Creswell, J \& Clark, P. (2011). Designing and conducting mixed methods research. $2^{\text {nd }}$ edition, Thousand Oaks, CA: Sage.

Croteau, M \& Raymond, L. (2004). Performance outcomes of strategic and IT competencies alignment. Journal of Information Technology, 19(3), 178-190. doi: https://doi.org/10.1057/palgrave.jit.2000020 
Davis, S \& Albright, T. (2004). An investigation of the effect of Balanced Scorecard implementation on financial performance. Management Accounting Research, 15(2), 135-153. https://doi.org/10.1016/j.mar.2003.11.001

Hair, J; Black, W; Babin, B \& Anderson, R. (2010). Multivariate Data Analysis. $7^{\text {th }}$ edition, Prentice Hall.

Harrison, J \& John, C. (1998). Foundations in strategic management. South-Western College.

Hilton, R; Maher, M \& Selto, F. (2003). Cost Management: Strategic for Business Decisions. $2^{\text {nd }}$ edition, McGraw Hill, North America.

Horngren, C; Dtar, S \& Rajan, M. (2012). Cost Accounting: A managerian emphasis. $6^{\text {th }}$ edition, Pearson Prentige Hall.

Janssens, W; Wijnen, K; Pelsmacker, P. and Kenhove, V. (2008). Marketing Research with SPSS, Prentice Hall.

Kaplan, R \& Norton, D. (2001). The Strategy-Focused Organization: How Balanced Scorecard Companies Thrive in the New Business Environment. $1^{\text {st }}$ edition. Harvard Business Review Press. https://doi.org/10.1108/s1.2001.26129cab.002

Kaplan, R \& Norton, D. (1992). The Balanced Scorecard-Measures That Drive Performance. Harvard Business Review, 70(1), 71 - 79. https://doi.org/10.1225/92105

Kaplan, R \& Norton, D. (1996). Using the Balanced Scorecard As A strategic Management System. Harvard Business Review, 74(1), 75 - 85. (Reprint \#96107.)

Lynch, R. (2006). Corporate Strategy. $4^{\text {th }}$ ed., prentice-Hall, Inc.

Malagueño, R; Lopez-Valeiras, E \& Gomez-Conde, J. (2018). Balanced scorecard in SMEs: effects on innovation and financial performance. Small Business Economics, 51(1), 221-244. https://doi.org/10.1007/s11187-017-9921-3

Malhotra, N.K., \& Stanton, S.C. (2004). Validating Inter-Object Interaction in Object-Oriented Designs. In: $4^{\text {th }}$ IASTED International Conference on Modeling, Simulation and Optimization, Kauai, Hawaii, USA.

Michaels, A. (2008). Critical Success Factors. WWW.//I: Critical Success Factors, html.

Muli, K. (2016). Extent of Balanced Scorecard Implementation and its effect on the Financial Performance of Small and Medium Enterprises in Nairobi County. Master Thesis, University of Nairobi.

Nair, M. (2004). Essentials of Balanced Scorecard. John Wiley \& Sons, Inc. https://doi.org/10.1002/9781118386774

Niven, P. (2002). Balanced Scorecard Step-by-Step: Maximizing Performance and Maintaining Results. John Wiley \& Sons, Inc.

Saad, R \& Daraghma, Z. (2016).Using of the Balanced Scorecard for Performance Evaluation: Empirical Evidence from the Listed Corporations in the Palestine Exchange (PEX). International Journal of Business and Management, 11(3), 215 - 222. https://doi.org/10.5539/ijbm.v11n3p215

Sweiti, I \& Lele, U. (2016). Impact of Balanced Scorecard Implementation on Financial Performance of Saudi Listed Companies. Journal of Behavioural Economics, Finance, Entrepreneurship, Accounting and Transport, 4(1), 8-12. https://doi.org/10.12691/jbe-4-1-2

Thompson, J \& Strickland, A. (2003). Strategic Management: Concepts \& Cases. $13^{\text {th }}$ edition, McGraw - Hill, North America.

Vecchio, R. (1995). Organizational Behavior, $3^{\text {rd }}$ ed., Prentice-Pryden Press, U.S.A.

Venkatraman, N, \& Ramanujam, V. (1986). Measurement of business performance in strategy research: A comparison approaches. The Academy of Management Review, 11(4), 801-814. https://doi.org/10.2307/258398 